\title{
IDENTIFIKASI KONDISI PSIKOLOGIS (MENTAL) PEMANAH JUNIOR DI DIY
}

\author{
Oleh: Suryanto \\ Dosen Jurusan Pendidikan Kesehatan dan Rekreasi FIK UNY
}

\begin{abstract}
Abstrak
Penelitian ini membahas tentang kondisi psikologis atlet junior cabang olahraga panahan di Daerah Istimewa Yogyakarta. Adapun tujuan yang ingin dicapai adalah untuk mengidentifikasi kondisi psikologis atlet junior cabang olahraga panahan di Daerah Istimewa Yogyakarta.

Penelitian ini merupakan penelitian deskriptif dengan menggunakan satu variabel, yaitu: kondisi psikologis. Populasi dalam penelitian ini adalah atlet junior cabang olahraga panahan di Daerah Istimewa Yogyakarta. Populasi berjumlah 32 orang dari 35 orang, karena 1 orang tidak hadir dan 2 orang tidak mengembalikan angket. Semua populasi digunakan sebagai sampel, sehingga disebut sampel total atau sensus. Instrumen yang digunakan untuk mengumpulkan data adalah angket. Untuk menganalisis data yang terkumpul, peneliti menggunakan teknik deskriptif kuantitatif dengan persentase.

Hasil penelitian menunjukkan bahwa kondisi psikologis atlet junior cabang olahraga panahan di Daerah Istimewa Yogyakarta terdiri atas (1) motivasi, (2) komunikasi, (3) kerjasama, (4) adaptasi, (5) inisiatif, dan (6) keyakinan, semuanya masuk dalam kategori Sangat Baik.
\end{abstract}

Kata kunci: kondisi psikologis, atlet junior di DIY

Pelatihan atau pembinaan atlet dilakukan dari tingkat pusat sampai daerah, dalam melatih setiap pelatih mempunyai prinsip atau konsep yang berbeda-beda, karena latar belakang dari pelatih juga berbeda-beda, misalnya tingkat pendidikan, pengalaman dan lain sebagainya.

Atlet pemula atau junior di dalam latihan harus dilakukan dengan sistem yang benar dan harus memperhatikan aspek-aspek penunjang yang diperlukan. Apabila sistem dalam latihan dan aspek penunjang kurang mendapat perhatian secara serius, kemungkinan besar calon atlet tersebut banyak mengalami masalah. Oleh sebab itu, seorang pelatih harus benar-benar menguasai segi fisik, teknik, taktik, dan psikologis (mental). 
Sampai saat ini pelatih masih banyak menekankan latihan pada atletnya hanya pada fisik, teknik, dan taktik saja, sedangkan faktor psikologis sama sekali tidak tersentuh. Menurut R. Feizal (2000: 19) dalam bertanding atlet akan menggunakan mentalnya sebesar $80 \%$, sedangkan taktik dan strategi hanya $20 \%$. Oleh karena itu, pelatihan mental pada saat mendekati pertandingan/kompetisi harus diprioritaskan.

Memperhatikan hal tersebut di atas, seorang pelatih tidak perlu ragu lagi memasukkan program psikologis setara bobotnya dengan latihan yang lain, karena pada saat bertanding $80 \%$ ditentukan oleh keadaan psikologis seorang atlet.

\section{KAJIAN PUSTAKA}

Menurut Kartini Kartono, dkk. (1989: 3) mental berasal dari kata Latin yang artinya jiwa atau sukma, sedangkan menurut R. Feizal (2000: 2) psikologi olahraga adalah ilmu yang mempelajari perilaku manusia dalam aktivitasnya sebagai seorang atlet.

R. Feizal (2000: 3-4) menyatakan bahwa psikologi sebagai ilmu pengetahuan yang bersangkut paut dengan perilaku dapat diamalkan dalam olahraga untuk:

1. Melakukan penelitian

2. Melakukan konseling

3. Mencetak atlet

4. Tes psikologi

5. Melakukan program khusus.

Untuk mencapai puncak prestasi menurut Donald Pandiangan (2000: 4) perlu program latihan secara baik dan melalui tahapan-tahapan, yaitu: (1) pembinaan fisik, (2) pembinaan teknik, (3) pembinaan taktik, (4) pembinaan mental, dan (5) pembinaan bertanding. Dengan demikian dalam membina atlet, pembinaan mental juga merupakan komponen yang tidak dapat dipisahkan dengan komponen lainnya.

Kondisi psikologis yang baik sangat dibutuhkan oleh seorang atlet, karena dengan memiliki kondisi psikologis yang baik kemungkinan besar seorang atlet akan memiliki ketegaran psikologis dalam setiap kompetisi atau kejuaraan. Memperhatikan hal tersebut, tugas seorang pelatih memang tidak ringan, apalagi atlet dalam waktu bertanding, akan selalu berada di bawah tekanan/stress, baik stress fisik maupun stress mental yang disebabkan oleh lawan, kawan bermain, penonton, pengaruh lingkungan dan lain sebagainya (Harsono, 1988: 243). Setiap olahragawan dalam mencapai stress secara berbeda, oleh sebab itu mereka harus dibimbing secara perorangan (Pate, et. al., 1984: 67).

1. Aspek-Aspek Psikologis yang Berperan dalam Olahraga

PB PBSI (2010: 2-5) menyatakan bahwa faktor psikologis pada atlet akan terlihat dengan jelas pada saat atlet tersebut bertanding. Beberapa masalah psikologis yang sering timbul di kalangan olahraga, khususnya dalam kaitannya dengan pertandingan dan masa latihan adalah sebagai berikut:

a. Berpikir positif 
Berpikir positif dimaksudkan sebagai cara berpikir yang mengarahkan sesuatu ke arah positif, melihat segi baiknya. Hal ini perlu dibiasakan bukan saja oleh atlet, tetapi bagi pelatih yang melatihnya. Dengan membiasakan diri berpikir positif, maka akan berpengaruh sangat baik untuk menumbuhkan rasa percaya diri, meningkatkan motivasi, dan menjalin kerjasama dengan berbagai pihak.

b. Penetapan Sasaran

Penetapan sasaran (goal setting) merupakan dasar dari latihan mental. Pelatih perlu membantu setiap atletnya untuk menetapkan sasaran, baik sasaran dalam latihan maupun dalam pertandingan.

c. Motivasi

Motivasi dapat dilihat sebagai suatu proses dalam diri seseorang untuk melakukan sesuatu sebagai usaha dalam mencapai tujuan tertentu. Motivasi yang kuat menunjukkan bahwa dalam diri orang tersebut tertanam dorongan kuat untuk dapat melakukan sesuatu.

d. Emosi

Faktor-faktor emosi dalam diri atlet menyangkut sikap dan perasaan atlet secara pribadi terhadap diri sendiri, pelatih maupun hal-hal lain di sekelilingnya. Bentuk-bentuk emosi dikenal sebagai perasaan, seperti senang, sedih, marah, cemas, takut, dan sebagainya. Bentuk-bentuk emosi tersebut terdapat pada setiap orang. Akan tetapi yang perlu diperhatikan di sini adalah bagaimana kita mengendalikan emosi tersebut agar tidak merugikan diri sendiri.

e. Kecemasan dan Ketegangan

Kecemasan biasanya berhubungan dengan perasaan takut akan kehilangan sesuatu, kegagalan, rasa salah, takut mengecewakan orang lain, dan perasaan tidak enak lainnya. Kecemasan-kecemasan tersebut membuat atlet menjadi tegang, sehingga bila ia terjun ke dalam pertandingan dapat dipastikan penampilannya tidak akan optimal.

f. Kepercayaan Diri

Dalam olahraga kepercayaan diri menjadi salah satu faktor penentu suksesnya seorang atlet. Masalah kurang atau hilangnya rasa percaya diri terhadap kemampuan diri sendiri akan mengakibatkan atlet tampil di bawah kemampuannya. Karena itu sesungguhnya atlet tidak perlu merasa ragu akan kemampuannya, sepanjang ia telah berlatih secara sungguh-sungguh dan memiliki pengalaman bertanding yang memadai.

g. Komunikasi

Komunikasi yang dimaksud adalah komunikasi dua arah, khususnya antara atlet dengan pelatih. Masalah yang sering timbul dalam hal kurang terjadinya komunikasi yang baik antara pelatih dengan atletnya adalah timbulnya salah pengertian yang menyebabkan atlet merasa diperlakukan tidak adil, sehingga tidak mau bersikap terbuka terhadap pelatih. 


\section{h. Konsentrasi}

Konsentrasi merupakan suatu keadaan dimana kesadaran seseorang tertuju kepada suatu objek tertentu dalam waktu tertentu. Makin baik konsentrasi seseorang, maka makin lama ia dapat melakukan konsentrasi. Dalam olahraga, konsentrasi sangat penting peranannya. Dengan berkurangnya atau terganggunya konsentrasi atlet pada saat latihan, apalagi pertandingan, maka akan timbul berbagai masalah.

i. Evaluasi Diri

Evaluasi diri dimaksudkan sebagai usaha atlet untuk mengenali keadaan yang terjadi pada dirinya sendiri. Hal ini perlu dilakukan agar atlet dapat mengetahui kelemahan dan kelebihan dirinya pada saat yang lalu maupun saat ini.

\section{Sejarah Panahan}

Sejak kapan anak panah digunakan, tidak dapat diketahui dengan pasti, yang jelas panah merupakan senjata paling tua yang digunakan oleh manusia sejak 50.000 tahun yang lalu, bahkan lebih tua lagi. Para Arkheologi memperkirakan dari lukisan di gua-gua yang sudah berumur kurang lebih 500.000 tahun. Selama ribuan tahun, umat manusia memakai panah untuk melindungi dirinya dari binatang-binatang liar. Dalam waktu yang bersamaan keahlian memanah merupakan suatu sarana untuk mencari makan. Panah merupakan simbol dari kekuatan dan kekuasaan. Hal ini memberikan status tertentu dan keberuntungan dalam lingkungannya.

Menurut kitab suci Bible, orang-orang Israel dan Mesir dikenal sebagai pemanahpemanah ulung. Hal itu dapat dibuktikan dengan berbagai pertempuran yang mengubah jalannya sejarah. Di Inggris, kebanyakan orang memakai busur yang panjang, sedang di Perancis orang-orang memakai busur silang (cross bowy). Orang-orang Yunani dan Turki membuat busur dari campuran kayu, tulang dan lilitan kulit. Hal yang menarik untuk dicatat bahwa sampai tahun 1959 para pemanah modern berhasil memecahkan rekor dengan busur kuno. Orang-orang turki mempunyai keunggulan dalam melemparkan panahnya 800 yard dengan pantulan busur yang membentuk "C" ketika tidak dibentangkan.

Setelah bubuk mesiu ditemukan, nilai busur sebagai senjata merosot tajam, tetapi panah tetap digunakan dalam saat-saat tertentu, seperti dalam perang Vietnam. Selama 25 tahun terakhir banyak orang mulai tertarik lagi dengan busur ketika S. Pope berhasil membidik 17 ekor singa Afrika dengan busur panjang. Bahkan sampai detik ini para pemburu mencoba untuk membidik binatang-binatang dari burung sampai beruang kelabu. Karena busur dan panah menjadi semakin popular, maka banyak Negara membuat Undang-undang khusus tentang senjata tersebut (Barrett, J.A., 1986: 10-11). 


\section{a. Panahan di Indonesia}

Keterikatan antara panah dengan cabang olahraga di Indonesia akan tampak dengan jelas, apabila kita mau mencermati lambang dari Gelora Bung Karno. Bung Karno sebagai pencetus ide untuk membangun gelanggang olahraga Senayan, memakai Kesatria yang sedang memanah. Tentunya Bung Karno memiliki alasan tersendiri, mengapa pecinta cerita wayang itu memakai Prabu Rama yang sedang memanah, sebagai lambang Gelora Senayan.

Tahun 1946, tidak lama setelah Indonesia berhasil memproklamirkan kemerdekaannya, dapat dikatakan merupakan tahun bersejarah dalam dunia Panahan sebagai media olahraga di Indonesia. Karena pada tahun itu Persatuan Olahraga Repubik Indonesia (PORI), sebagai sebuah induk dari kegiatan olahraga di Negara kita memasukkan Panahan sebagai salah satu cabang olahraga yang dilombakan, dan masuk menjadi anggota dari PORI. Sri Paku Alam VIII mendapat kehormatan untuk menjadi ketua dari olahraga memanah di Indonesia

Pada tahun 1948 ketika pesta olahraga tingkat nasional digelar, yaitu pada Pekan Olahraga Nasional (PON) yang pertama di Solo, pada cabang olahraga panahan diberi kesempatan untuk melakukan ekshibisinya yang pertama kali. Kemudian setelah mengalami masa ekshibisi, maka cabanng olahraga Panahan pada PON II hingga saat ini sudah dapat mengikuti perlombaan secara resmi.

Keikutsertaan cabang olahraga panahan dalam pesta olahraga tingkat Asia adalah pada pesta olahraga Asian Games IV yang diadakan pada tahun 1962 di Jakarta. Sebagai cabang olahraga pemula yang baru pertama kali ikut dalam pesta olahraga, maka keberadaan cabang olahraga panahan hanya sebatas pada tingkat ekshibisi saja. Cabang olahraga panahan pada Asian Games IV ini hanya diikiuti oleh tiga Negara, padahal Negara peserta dalam Asian Games IV berjumlah 17 negara. Hal ini dapat terjadi kemungkinan panahan pada pesta olahraga kali ini hanya bersifat ekshibisi saja, dan baru pertama kali didikutserakan. Sehingga kemungkinan banyak Negara peserta Asian Games IV belum mempersiapkan team panahan mereka. Ketiga peserta Negara itu adalah Indonesia, Jepang, dan Philipina (Harsuki, dkk. 2004: 259-261).

b. Perkembangan Panahan sebagai Sport

Henry VIII, seorang pemanah Inggris yang juga menyenangi pertaruhan. Hal itu dibuktikan dengan mengembangkan olahraga panahan sebagai pertandingan kompetisi. Sehingga klub-klub panahan mulai berdiri di Inggris 350 tahun yang lalu.

Turnamen panahan modern biasanya memakai sistem "tiga dan tiga" berdasarkan tradisi Inggris, yaitu 3 anak panah dalam sekali bidikan. Mulai diperkenalkan pada pertengahan tahun 1900. Klub paling tua di Amerika Serikat adalah kelompok Philadelphia yang berdiri tahun 1828. National Archery Association 
(NAA) dibentuk tahun 1879. Disusul kemudian dengan National Archery Field Archery dari California tahun 1939. Dalam Olympiade XX di Munich, Jerman Barat, yang diadakan pada musim panas tahun 1972, olahraga panahan termasuk yang memperoleh mendali emas, dan sudah berlangsung sejak tahun 1920. Apalagi setelah International Archery Federation (IAF) berdiri tahun 1930, olahraga panahan menjadi lebih mudah dikontrol.

National Collegiate Archery Cooches Association, kerapkali mempertemukan berbagai klub dan menjadi sponsor dalam kejuaraan panahan Nasional. Jumlah peserta telah bertambah dari 1,7 juta orang dalam tahun 1946, menjadi lebih dari 8 juta orang dalam tahun 1970. Panahan telah menjadi sport dunia modern.

c. Panah sebagai Media Olahraga

Panah sebagai sebuah media, dapat berperan ganda, karena panah tidak saja dapat dipergunakan sebagai senjata dalam sebuah peperangan atau untuk mencari makan dengan berburu di hutan, namun panah dapat pula dipergunakan sebagai media untuk kegiatan olahraga.

Inggris sebagai Negara penakluk di dunia, tentunya memiliki pasukan panah yang memang bagus yang dapat menyerang dan mengalahkan Negara yang akan ditaklukkannya. Inggris pula yang ikut mempelopori peran ganda dari panah, yaitu sebagai senjata untuk berperang dan sebagai media untuk berolahraga. Hal itu dibuktikan oleh Kaisar Charles II dari kerajaan Inggris pada tahun 1675, mengadakan lomba memanah bagi para Kesatria dan pasukannya.

Selain Charles II pada dekade yang sama, National Archery Association dari Amerika mengadakan pula kejuaraan memanah, karena panahan sudah merupakan salah satu cabang olahraga di sana. Inggris pada tahun 1844 mengulang kegiatan yang pernah diadakan oleh Charles II.

\section{METODE PENELITIAN}

Penelitian ini merupakan penelitian deskriptif. Populasi dalam penelitian ini adalah atlet junior cabang olahraga panahan di Daerah Istimewa Yogyakarta. Sampel dalam penelitian ini adalah semua atlet junior cabang olahraga panahan di Daerah Istimewa Yogyakarta yang berjumlah 32 orang dari 35 orang, karena 1 orang tidak hadir dan 2 orang tidak mengembalikan angket, sehingga disebut sampel total atau sensus.

Instrumen untuk mengetahui kondisi psikologis atlet junior cabang olahraga panahan menggunakan angket tertutup. Angket tersebut adalah Formulir-C, yaitu monitoring kondisi psikologis dari Pusat Pelaksanaan Latihan (PPL) KONI Pusat. Instrumen terdiri atas 2 alternatif jawaban, yaitu ADA dan TIDAK. Ke dua jawaban tersebut diberi bobot skor, yaitu pertanyaan jawaban $\mathrm{YA}=1$ dan $\mathrm{TIDAK}=0$. Setelah instrumen dan bobot penyekoran sudah ditentukan, langkah berikutnya adalah menyebarkan angket ke 
responden, mengambil kembali angket setelah diisi oleh responden, menjumlahkan seluruh skor jawaban, membandingkan dengan skor yang diharapkan, dan membuat persentase.

\section{HASIL PENELITIAN DAN PEMBAHASAN}

Kondisi psikologis (mental) atlet junior cabang olahraga panahan di Daerah Istimewa Yogyakarta dideskripsikan berdasarkan jawaban para atlet junior panahan atas angketangket yang telah disebarkan. Pendeskripsian data dilakukan dengan mengkategorikan kondisi psikologis atlet junior cabang olahraga panahan di Daerah Istimewa Yogyakarta serta pengkategorian tiap-tiap faktornya yang meliputi motivasi, komunikasi, kerja sama, adaptasi, inisiatif, dan keyakinan.

Berikut disajikan hasil analisis data tentang kondisi psikologis atlet junior cabang olahraga panahan di Daerah Istimewa Yogyakarta.

\section{Motivasi Atlet Junior Cabang Olahraga Panahan di Daerah Istimewa Yogyakarta}

Motivasi atlet junior cabang olahraga panahan di Daerah Istimewa Yogyakarta dideskripsikan berdasarkan angket yang berjumlah 4 butir. Skor penilaian tiap item adalah 0 dan 1 , sehingga nilai maksimal yang mungkin diperoleh adalah 4 dan minimal 0 . Selanjutnya skor diubah dalam bentuk persentase, yaitu menghitung skor pencapaian persentase tiap atlet terhadap skor maksimum. Analisis menghasilkan persentase terendah sebesar $50 \%$ dan maksimal $100 \%$. Rerata pencapaian persentase sebesar $86,72 \%$ dengan median $100 \%$, modus $100 \%$ dan standar deviasi (SD) 16,78 .

Distribusi frekuensi motivasi atlet junior cabang olahraga panahan di Daerah Istimewa Yogyakarta dapat dilihat pada tabel berikut:

\section{Tabel 1. Distribusi Frekuensi Motivasi Atlet Junior Cabang Olahraga Panahan di Daerah Istimewa Yogyakarta}

\begin{tabular}{|c|c|c|c|c|}
\hline \multirow{2}{*}{ No. } & \multirow{2}{*}{ Kategori } & \multirow{2}{*}{$\begin{array}{c}\text { Rentang Skor } \\
(\%)\end{array}$} & \multicolumn{2}{|c|}{ Frekuensi } \\
\cline { 4 - 5 } & & $>75$ s.d. 100 & 18 & 56.25 \\
\hline 1. & Sangat Baik & $>50$ s.d. 75 & 11 & 34.38 \\
\hline 2. & Baik & $>25$ s.d. 50 & 3 & 9.38 \\
\hline 3. & Cukup & 0 s.d. 25 & 0 & 0.00 \\
\hline 4. & Kurang & 32 & 100.00 \\
\hline \multicolumn{4}{|c|}{ Jumlah } \\
\hline
\end{tabular}


Berdasarkan tabel di atas terlihat bahwa sebagian besar atlet junior cabang olahraga panahan memiliki motivasi yang Sangat Baik dengan frekuensi persentase sebesar 56,25 $\%$. Jika dilihat rerata skor persentase sebesar 86,72\%, dapat disimpulkan bahwa motivasi atlet junior cabang olahraga panahan di Daerah Istimewa Yogyakarta adalah Sangat Baik.

\section{Komunikasi Atlet Junior Cabang Olahraga Panahan di Daerah Istimewa Yogyakarta}

Komunikasi atlet junior cabang olahraga panahan di Daerah Istimewa Yogyakarta dideskripsikan berdasarkan angket yang berjumlah 4 butir. Analisis menghasilkan skor persentase terendah dari jawaban atlet sebesar $50 \%$ dan maksimal $100 \%$. Rerata pencapaian persentase sebesar 83,59\% dengan median $75 \%$, modus $100 \%$ dan standar deviasi (SD) 17,52 .

Distribusi frekuensi komunikasi atlet junior cabang olahraga panahan di Daerah Istimewa Yogyakarta dapat dilihat pada tabel berikut:

Tabel 2. Distribusi Frekuensi Komunikasi Atlet Junior Cabang Olahraga Panahan di Daerah Istimewa Yogyakarta

\begin{tabular}{|c|c|c|c|c|}
\hline \multirow{2}{*}{ No. } & \multirow{2}{*}{ Kategori } & \multirow{2}{*}{$\begin{array}{c}\text { Rentang Skor } \\
(\%)\end{array}$} & \multicolumn{2}{|c|}{ Frekuensi } \\
\cline { 4 - 5 } & & & Absolut & Persentase \\
\hline 1. & Sangat Baik & $>75$ s.d. 100 & 15 & 46.88 \\
\hline 2. & Baik & $>50$ s.d. 75 & 13 & 40.63 \\
\hline 3. & Cukup & $>25$ s.d. 50 & 4 & 12.50 \\
\hline 4. & Kurang & 0 s.d. 25 & 0 & 0.00 \\
\hline \multicolumn{2}{|c|}{ Jumlah } & 32 & 100.00 \\
\hline
\end{tabular}

Berdasarkan tabel di atas terlihat bahwa sebagian besar atlet junior cabang olahraga panahan memiliki komunikasi yang Sangat Baik dengan frekuensi persentase sebesar $46,88 \%$. Jika dilihat rerata skor persentase sebesar 83,59 \%, dapat disimpulkan bahwa komunikasi atlet junior cabang olahraga panahan di Daerah Istimewa Yogyakarta adalah Sangat Baik.

\section{Kerja Sama Atlet Junior Cabang Olahraga Panahan di Daerah Istimewa Yogyakarta}

Kerja sama atlet junior cabang olahraga panahan di Daerah Istimewa Yogyakarta dideskripsikan berdasarkan angket yang berjumlah 5 butir. Analisis menghasilkan skor persentase terendah dari jawaban atlet sebesar $40 \%$ dan maksimal $100 \%$. Rerata pencapaian persentase sebesar $76,88 \%$ dengan median $80 \%$, modus $80 \%$ dan standar deviasi (SD) 16,15 . 
Distribusi frekuensi kerja sama atlet junior cabang olahraga panahan di Daerah Istimewa Yogyakarta dapat dilihat pada tabel berikut:

Tabel 3. Distribusi Frekuensi Kerjasama Atlet Junior Cabang Olahraga Panahan di Daerah Istimewa Yogyakarta

\begin{tabular}{|c|c|c|c|c|}
\hline \multirow{2}{*}{ No. } & \multirow{2}{*}{ Kategori } & \multirow{2}{*}{$\begin{array}{c}\text { Rentang Skor } \\
(\%)\end{array}$} & \multicolumn{2}{|c|}{ Frekuensi } \\
\hline & & & Absolut & Persentase \\
\hline 1. & Sangat Baik & $>75$ s.d. 100 & 21 & 65.63 \\
\hline 2. & Baik & $>50$ s.d. 75 & 10 & 31.25 \\
\hline 3. & Cukup & $>25$ s.d. 50 & 1 & 3.13 \\
\hline 4. & Kurang & 0 s.d. 25 & 0 & 0.00 \\
\hline \multicolumn{3}{|c|}{ Jumlah } & 32 & 100.00 \\
\hline
\end{tabular}

Berdasarkan tabel di atas terlihat bahwa sebagian besar atlet junior cabang olahraga panahan memiliki kerjasama yang Sangat Baik dengan frekuensi persentase sebesar 65,63 $\%$. Jika dilihat rerata skor persentase sebesar $83,59 \%$, dapat disimpulkan bahwa kerja sama atlet junior cabang olahraga panahan di Daerah Istimewa Yogyakarta adalah Sangat Baik.

4. Adaptasi Atlet Junior Cabang Olahraga Panahan di Daerah Istimewa Yogyakarta Adaptasi atlet junior cabang olahraga panahan di Daerah Istimewa Yogyakarta dideskripsikan berdasarkan angket yang berjumlah 4 butir. Analisis menghasilkan skor nilai seluruh atlet adalah maksimal, dengan kata lain skor persentase seluruh atlet adalah $100 \%$. Oleh karena itu nilai standar deviasi (SD) adalah 0 .

Distribusi frekuensi adaptasi atlet junior cabang olahraga panahan di Daerah Istimewa Yogyakarta dapat dilihat pada tabel berikut:

Tabel 4. Distribusi Frekuensi Adaptasi Atlet Junior Cabang Olahraga Panahan di

Daerah Istimewa Yogyakarta

\begin{tabular}{|c|c|c|c|c|}
\hline \multirow{2}{*}{ No. } & \multirow{2}{*}{ Kategori } & \multirow{2}{*}{$\begin{array}{c}\text { Rentang Skor } \\
(\mathbf{\%})\end{array}$} & \multicolumn{2}{|c|}{ Frekuensi } \\
\cline { 4 - 5 } & & Absolut & Persentase \\
\hline 1. & Sangat Baik & $>75$ s.d. 100 & 32 & 100.00 \\
\hline 2. & Baik & $>50$ s.d. 75 & 0 & 0.00 \\
\hline 3. & Cukup & $>25$ s.d. 50 & 0 & 0.00 \\
\hline 4. & Kurang & 0 s.d. 25 & 0 & 0.00 \\
\hline \multicolumn{3}{|c|}{ Jumlah } & 32 & 100.00 \\
\hline
\end{tabular}


Berdasarkan tabel di atas terlihat bahwa seluruh atlet junior cabang olahraga panahan memiliki adaptasi yang Sangat Baik dengan frekuensi persentase sebesar $100 \%$. Oleh karena itu dapat disimpulkan bahwa adaptasi atlet junior cabang olahraga panahan di Daerah Istimewa Yogyakarta adalah Sangat Baik.

\section{Inisiatif Atlet Junior Cabang Olahraga Panahan di Daerah Istimewa Yogyakarta}

Inisiatif atlet junior cabang olahraga panahan di Daerah Istimewa Yogyakarta dideskripsikan berdasarkan angket yang berjumlah 3 butir. Analisis menghasilkan skor persentase terendah dari jawaban atlet sebesar $66,67 \%$ dan maksimal $100 \%$. Rerata pencapaian persentase sebesar $97,92 \%$ dengan median dan modus sebesar $100 \%$ serta standar deviasi (SD) 8,20.

Distribusi frekuensi inisiatif atlet junior cabang olahraga panahan di Daerah Istimewa Yogyakarta dapat dilihat pada tabel berikut:

Tabel 5. Distribusi Frekuensi Inisiatif Atlet Junior Cabang Olahraga Panahan di Daerah Istimewa Yogyakarta

\begin{tabular}{|c|c|c|c|c|}
\hline \multirow{2}{*}{ No. } & \multirow{2}{*}{ Kategori } & \multirow{2}{*}{$\begin{array}{c}\text { Rentang Skor } \\
(\%)\end{array}$} & \multicolumn{2}{|c|}{ Frekuensi } \\
\hline & & & Absolut & Persentase \\
\hline 1. & Sangat Baik & $>75$ s.d. 100 & 30 & 93,75 \\
\hline 2. & Baik & $>50$ s.d. 75 & 2 & 6,25 \\
\hline 3. & Cukup & $>25$ s.d. 50 & 0 & 0.00 \\
\hline 4. & Kurang & 0 s.d. 25 & 0 & 0.00 \\
\hline \multicolumn{3}{|c|}{ Jumlah } & 32 & 100.00 \\
\hline
\end{tabular}

Berdasarkan tabel di atas terlihat bahwa sebagian besar atlet junior cabang olahraga panahan memiliki inisiatif yang Sangat Baik dengan frekuensi persentase sebesar 93,75 $\%$. Jika dilihat rerata skor persentase sebesar $97,92 \%$, dapat disimpulkan bahwa inisiatif atlet junior cabang olahraga panahan di Daerah Istimewa Yogyakarta adalah Sangat Baik.

\section{Keyakinan Atlet Junior Cabang Olahraga Panahan di DIY}

Keyakinan atlet junior cabang olahraga panahan di Daerah Istimewa Yogyakarta dideskripsikan berdasarkan angket yang berjumlah 4 butir. Analisis menghasilkan skor persentase terendah dari jawaban atlet sebesar $50 \%$ dan maksimal $100 \%$. Rerata pencapaian persentase sebesar 89,84 \% dengan median dan modus sebesar $100 \%$ serta standar deviasi (SD) 14,00.

Distribusi frekuensi keyakinan atlet junior cabang olahraga panahan di Daerah Istimewa Yogyakarta dapat dilihat pada tabel berikut: 
Tabel 6. Distribusi Frekuensi Keyakinan Atlet Junior Cabang Olahraga Panahan di Daerah Istimewa Yogyakarta

\begin{tabular}{|c|c|c|c|c|}
\hline \multirow{2}{*}{ No. } & \multirow{2}{*}{ Kategori } & \multirow{2}{*}{$\begin{array}{c}\text { Rentang Skor } \\
(\%)\end{array}$} & \multicolumn{2}{|c|}{ Frekuensi } \\
\hline & & & Absolut & Persentase \\
\hline 1. & Sangat Baik & $>75$ s.d. 100 & 20 & 62.50 \\
\hline 2. & Baik & $>50$ s.d. 75 & 11 & 34.38 \\
\hline 3. & Cukup & $>25$ s.d. 50 & 1 & 3.13 \\
\hline 4. & Kurang & 0 s.d. 25 & 0 & 0.00 \\
\hline \multicolumn{3}{|c|}{ Jumlah } & 32 & 100.00 \\
\hline
\end{tabular}

Berdasarkan tabel di atas terlihat bahwa sebagian besar atlet junior cabang olahraga panahan memiliki keyakinan yang Sangat Baik dengan frekuensi persentase sebesar 62,50 $\%$. Jika dilihat rerata skor persentase sebesar $89,84 \%$, dapat disimpulkan bahwa keyakinan atlet junior cabang olahraga panahan di Daerah Istimewa Yogyakarta adalah Sangat Baik.

Rangkaian analisis di atas menunjukkan bahwa faktor yang menyusun kondisi psikologis atlet junior cabang olahraga panahan di Daerah Istimewa Yogyakarta keseluruhannya berada pada kondisi Sangat Baik. Selanjutnya analisis dilanjutkan dengan menganalisis keseluruhan jawaban atlet terhadap keseluruhan item yang berjumlah 24 butir. Jika jawaban atlet seluruhnya mendapat nilai 1, pencapaian skor persentase adalah $100 \%$, sebaliknya jika skor seluruh atlet adalah 0 , maka persentase yang diperoleh adalah $0 \%$. Berdasarkan jawaban atlet terlihat bahwa skor persentase terkecil adalah $75 \%$ dan maksimal $100 \%$. Rerata yang diperoleh sebesar 88,28 \% dengan median 87,50 \% dan modus $91,67 \%$ serta standar deviasi (SD) 6,21. Distribusi frekuensi kondisi psikologis atlet junior cabang olahraga panahan di Daerah Istimewa Yogyakarta tampak dalam tabel berikut:

Tabel 7. Distribusi Frekuensi Kondisi Psikologis (Mental) Atlet Junior Cabang Olahraga Panahan di Daerah Istimewa Yogyakarta

\begin{tabular}{|c|c|c|c|c|}
\hline \multirow{2}{*}{ No. } & \multirow{2}{*}{ Kategori } & \multirow{2}{*}{$\begin{array}{c}\text { Rentang Skor } \\
(\%)\end{array}$} & \multicolumn{2}{|c|}{ Frekuensi } \\
\hline & & & Absolut & Persentase \\
\hline 1. & Sangat Baik & $>75$ s.d. 100 & 31 & 96.88 \\
\hline 2. & Baik & $>50$ s.d. 75 & 1 & 3.13 \\
\hline 3. & Cukup & $>25$ s.d. 50 & 0 & 0.00 \\
\hline 4. & Kurang & 0 s.d. 25 & 0 & 0,00 \\
\hline \multicolumn{3}{|c|}{ Jumlah } & 32 & 100.00 \\
\hline
\end{tabular}


Berdasarkan tabel di atas terlihat bahwa sebagian besar atlet junior cabang olahraga panahan memiliki kondisi psikologis yang Sangat Baik dengan frekuensi persentase sebesar $96,88 \%$. Jika dilihat rerata skor persentase sebesar 88,28 \%, maka dapat disimpulkan bahwa kondisi psikologis atlet junior cabang olahraga panahan di Daerah Istimewa Yogyakarta adalah Sangat Baik.

Keseluruhan rangkaian analisis dari tiap faktor kondisi psikologis sampai dengan total keseluruhan faktor di atas dapat dirangkum dalam tabel berikut:

Tabel 8. Pencapaian Skor Persentase Kondisi Psikologis (Mental) Atlet Junior Cabang Olahraga Panahan di Daerah Istimewa Yogyakarta

\begin{tabular}{|c|l|c|c|c|c|c|}
\hline \multirow{2}{*}{ No. } & \multirow{2}{*}{$\begin{array}{c}\text { Komponen Kondisi } \\
\text { Psikologis }\end{array}$} & \multicolumn{5}{|c|}{ Nilai } \\
\cline { 3 - 6 } & & A & B & C & D & \multirow{2}{*}{ Total } \\
\cline { 3 - 6 } & & Sangat Baik & Baik & Cukup & Kurang & \\
\hline 1. & Motivasi & 18 & 11 & 3 & 0 & 32 \\
\hline 2. & Komuikasi & 15 & 13 & 4 & 0 & 32 \\
\hline 3. & Kerjasama & 21 & 10 & 1 & 0 & 32 \\
\hline 4. & Adaptasi & 32 & 0 & 0 & 0 & 32 \\
\hline 5. & Inisiatif & 30 & 2 & 0 & 0 & 32 \\
\hline 6. & Keyakinan & 20 & 11 & 1 & 0 & 32 \\
\hline
\end{tabular}

Berdasarkan hasil penelitian, ke enam komponen kondisi psikologis atlet junior cabang olahraga panahan di Daerah Istimewa Yogyakarta yang terdiri atas (1) motivasi, (2) komunikasi, (3) kerjasama, (4) adaptasi, (5) inisiatif, (6) keyakinan, semuanya masuk dalam kategori Sangat Baik. Kemungkinan ini atlet junior di Daerah Istimewa Yogyakarta sudah mempunyai kematangan mental, karena atlet sudah sering mengikuti kompetisi dengan atlet panahan di Daerah Istimewa Yogyakarta maupun di luar Daerah Iatimewa Yogyakarta. Di samping itu atlet sudah berlatih sesuai program yang telah ditentukan dan siap diterjunkan ke dalam pertandingan, maka atlet telah membekali diri dengan kemampuan-kemampuannya.

Menurut Harsono (1988: 247) kemampuan-kemampuan tersebut meliputi: (1) bertahan terhadap frustasi. Seorang atlet yang matang, memiliki daya ketahanan individual yang besar tarhadap frustasi; (2) menatap tekanan dengan kesadaran dan pikiran yang wajar. Seorang atlet yang matang (mature) memiliki kemampuan yang tinggi dalam menggunakan reason (akal sehat) dan loqic. Dia juga mampu untuk mengkontrol rasa cemas pada waktu menatap atau menghadapi gangguan-gangguan fisik, emosi, dan mental; (3) menerima kegagalan secara inteligen. Atlet yang mature memiliki kemampuan untuk menerima kegagalan secara inteligen, dia pelajari dan selidiki sebab dari kegagalan dengan penuh pengertian (insight) dan kewajaran. 
Walaupun hasil penelitian menunjukkan bahwa ke enam komponen kondisi psikologis atlet junior cabang olahraga panahan di Daerah Istimewa Yogyakarta semuanya masuk dalam kategori Sangat Baik, tetapi komponen komunikasi memiliki persentase paling rendah, kemungkinan ini dipengaruhi oleh kurang terjalinnya komunikasi yang baik antara pelatih dengan atletnya adalah timbulnya salah pengertian, sehingga atlet tidak mau bersikap terbuka terhadap pelatih. Untuk menghindari hambatan komunikasi, pelatih perlu menyesuaikan teknik-teknik komunikasi dengan atlet seraya memperhatikan asas individual. Keterbukaan pelatih dalam hal program latihan akan membantu terjalinnya komunikasi yang baik, asalkan dilakukan secara objektif dan konsekuen. Sebelum program latihan dijalankan perlu dijelaskan dan dibuat peraturan mengenai tata tertib latihan dan aturan main lainnya termasuk sanksi yang dikenakan jika terjadi pelanggaran terhadap peraturan yang telah dibuat tersebut (PB PBSI, 2010: 4).

\section{KESIMPULAN DAN SARAN}

Berdasarkan hasil analisis data dan pembahasan dapat disimpulkan bahwa kondisi psikologis (mental) atlet junior cabang olahraga panahan di DIY dalam kategori Sangat Baik. Secara rinci, komponen kondisi psikologis atlet junior cabang olahraga panahan di Daerah Istimewa Yogyakarta adalah (1) motivasi masuk dalam kategori Sangat Baik, (2) komunikasi masuk dalam kategori Sangat Baik, (3) kerjasama masuk dalam kategori Sangat Baik, (4) adaptasi masuk dalam kategori Sangat Baik, (5) inisiatif masuk dalam kategori Sangat Baik, dan (6) keyakinan masuk dalam kategori Sangat Baik.

Berdasarkan hasil penelitian ini, peneliti menyarankan kepada pembina dan pelatih panahan junior di Daerah Istimewa Yogyakarta, agar mempertahankan kualitas pembinaan dan memonitor kondisi psikologis atlet junior secara rutin.

\section{DAFTAR PUSTAKA}

Dahara Prize. (1986). Olahraga Panahan, Pedoman, Teknik \& Analisa. (Disadur dari Barrett, J.A.). Semarang: Effhar Offset.

Donald Pandiangan. (2000). "Sistem Pemanduan Bakat". Makalah Penataran Pelatib Panaban Tingkeat Dasar. Jakarta: PERPANI.

Harsono. (1988). Coaching dan Aspek-aspek Psikologis dalam Coaching. Jakarta: Depdikbud.

Harsuki, dkk. (2004). Olabraga Indonesia dalam Persepektif Sejarah (Periode Tahun 19451965). Jakarta: Depdiknas

Kartini Kartono, dkk. (1989). Hygiene Mental dan Kesehatan Mental dalam Islam. Bandung: Mandar Maju.

Pate, R.R. et. al., (1984). Scientific Foundations of Coacbing. New York: Saunders College Publishing. 
PB PBSI. (2010). "Psikologi Olahraga". http://www.bulutangkis.com/mod.php? mod"userpage \&menu"403\&p.

R. Feizal. (2000). "Psikologi Olahraga". Makalah Penataran Pelatib Panahan Tingkat Dasar. Jakarta: PERPANI. 